AGRICULTURE AND BIOLOGY JOURNAL OF NORTH AMERICA

ISSN Print: 2151-7517, ISSN Online: 2151-7525, doi:10.5251/abjna.2012.3.4.140.144

(C) 2012, ScienceHuß, http://www.scihub.org/ABJNA

\title{
Study of equinine influenza in the region of Khenchela (Algeria).
}

\section{Dr. EI-Hacene BERERHI ${ }^{1}$, Dr. Rachid KABOUIA', Dr. Omar BOUAZIZ1 , and ${ }^{1}$ Nedjoua LAKHDARA, Amira Leila DIB}

\author{
Laboratory Management The Animal Health and Production \\ Department of veterinary science Constantine \\ Faculty of Science and The Nature Of Life, University Mentouri Constantine \\ ABSTRACT
}

The objective of this study was to evaluate the prevalence of respiratory viral infections in horses.In this perspective we looked for antibodies to influenza in 132 horses with chronic respiratory diseases, all stationed in the area Khenchela, situated north-east of Constantine (Algeria). Horses played an important socio-economic role. In many rural areas, horses were regularly used as a pulling force for animal traction and transport people and goods. They contributed greatly to the increase in agricultural production and improve socio-economic conditions of the rural populations. The results showed that on the132 sera tested, of which 32 were positive (ie 24.24 percent): 30 to test for the inhibition of the hemagglutination and 2 to the reaction of complement fixation. These results were discussed in relation to those observed by other authors.

Keywords: horse, equine influenza virus, inhibition of hemagglutination , complement fixation, Epidemiology.

\section{INTRODUCTION}

Medicine Horse is still marked by the high incidence of respiratory viral, mechanical and allergic .

Their etiology and seroprevalence still poorly explained (Chabchoub et al., 2011; Lucam et al., 1999). However, the health situation of the horse herd in Algeria is still threatened by the occurrence of certain infectious and contagious diseases that cause severe morbidity and sometimes mortality in infected flocks. The equine influenza causes significant economic losses, immobilizes the positive sera and disrupts sports (Chabchoub et al. 2002; Fontaine, 1989; Jomaa, 1993; Authie, 1989).

In Algeria, the information on the epidemiology of this disease are lacking. We found it useful to conduct a sero-epidemiological study to assess the prevalence of this disease entity.

\section{MATERIALS AND METHODS}

\section{Material}

Population surveyed: The equine population is relatively importante at Khenchela. According to statistics from the Ministry of Agriculture (2006), it has 850 horses including 568 adults and 282 within two years. These are composed of Barbe horses, barbe Arab and derivatives of barbe, they belong to traditional farms. There is no national program to fight against these epidemics. These geographical features of the equine population in this region led us to choose the area of El Hamma and Mahmel located northeast of Khenchela; To achieve our epidemiological investigation. These two regions are respectively representative of the population of Barb horses and arab beards and donkey.

Animals: Our study was conducted from January to December 2006. The number of horses were 132. These animals had presented chronic bronchopulmonary diseases. The diagnosis was made on the basis of the memorial and clinical examination (cough and dyspnea lasting for 3 months).

Methods: The serum was obtained from the jugular vein of the animals studied, a single blood test was performed. The sampling sites were chosen in collaboration with veterinary services, technical staff and horse owners based on the grouping of horses. The animals were aged 4 to 13 years. The $20 \mathrm{ml}$ blood sample was taken from the jugular vein in vacutainer tubes of $10 \mathrm{ml}$. Sera were divided into aliquots and stored at $-20^{\circ} \mathrm{C}$ before serological examinations. Of 132 serum samples collected, 60 were mules and 72 were of equine. They were tested in the laboratory AFSSA (French Agency for Health and Food Safety, Paris). 
-Research of anti-influenza

\section{Stem-viral}

The antigens of virus subtype 1 and type 2 and the control antisera (positive and negative) were provided by the laboratory AFSSA Paris. For the analysis of test sera, two serological diagnostic techniques recommended by the Office International of Epizooties are used (Sgiura et al. 2001; Timoney, 2002).

Test of reaction-inhibiting hemagglutinin: It is a technique in micro method, carried on round bottom plate, which had been used. Positive control sera from animals with a high titer of antibodies. Antiinfluenza, had been employed. The positive control sera, titre 512, were used at a dilution of $1 / 10$ th. Test sera were inactivated at $56^{\circ} \mathrm{C}$ for 30 minutes and were in contact (volume / volume) with a suspension of chicken erythrocytes to $20 \%$ in PBS (phosphate buffered saline-Bio Mérieux) for 30 minutes.

\section{complement fixation test:}

For the detection of complement-fixing antibodies in sera collected horses, the technique LBCF (Laboratory Branch Complement Fixation), adapted to micromethod plate, was used (Anestad G et al. In 2000). Sera were decomplemented at $56^{\circ} \mathrm{C}$ for 30 minutes. They were freshly diluted in a geometric progression of ratio 2 from the initial dilution of $1 / 8$ and placed at $25 \mu \mathrm{l}$ per well of a 96 well plate. The antigen diluted to $1 / 4$ in Veronal buffer $\mathrm{pH} 7.3$, to contain an antigenic unit in a volume of $25 \mu$ l per well and the plate was incubated 10 minutes at room temperature. The complement pretitration before each reaction was added at $2 \mathrm{IU}$ by $50 \mu \mathrm{l}$ per well and the plate placed at $37^{\circ} \mathrm{C}$ for 30 minutes. The haemolytic system using sheep red blood cells to $2 \%$ in Veronal buffer $\mathrm{pH}$ 7.3. The serum hemolytic was a sheep serum anti-red blood cells prepared in rabbits and used at a dilution of $1 / 500$. The sensitization of erythrocytes were carried out at the time . Reading the plaque was $100 \%$ inhibition of hemolysis: a serum was considered positive if it had a title of 8 or more.

\section{RESULTS}

As part of the survey, 132 sera donkeys and horses had been tested, of which 32 were positive (ie 24.24\%): 30 to test hemagglutination inhibition and 2 to the fixation complément. The results obtained in the various areas visited (Table 1) showed that antibodies against the virus of equine influenza was detected in all areas.

Table 1: Serological prevalence of equine influenza in different areas visited

Place visited

\begin{tabular}{lccccccc} 
& \multicolumn{1}{l}{$\mathrm{Nb} \%$} & & \multicolumn{1}{l}{$\mathrm{IH}(\mathrm{nb})$} & $\mathrm{IH} \% \mathrm{Rfc}(\mathrm{nb}) \mathrm{Rfc}(\%)$ \\
El-Hamma & 72 & 18 & 25 & 18 & 100 & 0 & 0 \\
Mahmel & 60 & 14 & 23,33 & 12 & 85,71 & 2 & 14,28 \\
Total & 132 & 32 & 24,24 & 30 & 93,75 & 2 & 6,25
\end{tabular}

$\mathrm{IH}$ : Inhibition of hemagglutination, RFC: complement fixation reaction, Nb: Number

All positive serum samples from areas of El Hamma and Mahmel, contained antibodies inhibited haemagglutinin (or $93.75 \%$ ). Those who were positive for complement fixation reaction were detected only in the area Mahmel (6.25\%). The distribution of subtypes of the virus was deferred based on the places visited (Table 2). 
Table 2: Distribution by locality visited subtypes of the virus

\begin{tabular}{lccccccc}
$\begin{array}{l}\text { Place } \\
\text { visited }\end{array}$ & \multicolumn{2}{c}{$\begin{array}{l}\text { Nb. positive } \\
\text { sera }\end{array}$} & \multicolumn{2}{c}{$\begin{array}{c}\text { Positive sera } \\
\text { subtype1 }\end{array}$} & \multicolumn{2}{c}{$\begin{array}{c}\text { positive sera } \\
\text { subtype2 }\end{array}$} & \multicolumn{2}{c}{$\begin{array}{c}\text { positive sera } \\
\text { subtypes1and2* }\end{array}$} \\
El-Hamma & 18 & 2 & 11,11 & 11 & 61,11 & 5 & 27,77 \\
Mahmel & 14 & 0 & 0 & 8 & 57,14 & 6 & 42,85 \\
Total & 32 & 2 & 6,25 & 19 & 59,37 & 11 & 34,37
\end{tabular}

* Mixed Infection

Thus, in the type 1 infections involving subtypes 1 and 2 of the flu virus had been identified in all regions covered by the survey, except Mahmel, where antibodies against the only sub- type 2 were identified.

The latter prevailed in all the areas visited: it was detected in $61.11 \%$ of sera tested positive in the zone of El Hamma. A Mahmel the prevalence of antibodies against subtype 2 was $57.14 \%$. The prevalence rate of antibodies against a subtype of the virus was more important in El Hamma (11.11\%) than when it was Mahmel negative $(0 \%)$.

The prevalence rate was varied with animal species (Table 3 ), it was higher in donkeys ( $31.66 \%$ ) and reached only $(18.05 \%)$ in horses.

Table 3: Distribution of sera tested by race

Species Nb. sera tested

\begin{tabular}{|c|c|c|c|c|c|c|c|}
\hline & $\mathrm{Nb}$ & $\%$ & & & $\mathrm{IH}(\%)$ & $\operatorname{RFC}(\mathrm{nb})$ & RFC(\% \\
\hline mules & 60 & 19 & 31,66 & 18 & 94,73 & 1 & 5,26 \\
\hline Equine & 72 & 18,05 & & 12 & 92,30 & 1 & 7,69 \\
\hline Total & 132 & 24,24 & & 30 & 93,75 & 2 & 6,25 \\
\hline
\end{tabular}

The antibodies which inhibited haemagglutinin were identified in $94.73 \%$ of donkeys tested positive, while those fixing the complements were detected in 5.26\% of these animals. In horses, the prevalence rate of these two types of antibodies is $92.30 \%$ and $7.69 \%$.
Because of the disparities that existed in the number of sera collected by age, the results for the rate of infection had not concluded that there was a correlation between age and degree of responsiveness animals with the disease (Table 4).

Table 4: Results by Age Group of serological tests.

$\begin{array}{lcrr}\text { Age group } & \text { Nb. sera tested } & \text { Nb. Positive sera } & \text { \% Positive sera } \\ 4-5 \text { years } & 43 & 15 & 34,88 \\ \text { 6-10years } & 80 & 14 & 17,50 \\ \text { 11-13years } & 09 & 03 & 33,33 \\ & & & \\ \text { Total } & 132 & 32 & 24,24\end{array}$




\section{DISCUSSION}

The samples tested were sera unique. Two diagnostic techniques were used in parallel: the test of hemagglutination inhibition and complement fixation reaction (Sgiura et al. 2001; Timoney, 2002; Anestad et al., 2000). The choice of the method was justified by the fact that the antibodies inhibited haemagglutinin persisted longer in serum and demonstration was proof of the existence of old infections. The second technique, however, to detect complement-fixing antibodies, evidence of recent infection (Sidibé et al. In 2002 in Mali Bousseta et al., 2000 in Tunisia, Fontaine et al. , 1989 in France, Le Minor et al., 1982 in France Zientara andColl., 2002 in France ).

In areas of the study, the infection rate of horses was $24.24 \%$. The antibodies showed the result of natural infection because the animals with these antibodies had never been vaccinated against influenza. They were directed against the subtype 1 and 2 of the disease virus. The survey had found that in the town of El Hamma had circulated a subtype of influenza virus with a prevalence of $11.11 \%$, it was absent in the locality of Mahmel; subtype 2 was present in both locations with a prevalence equal to $61.11 \%$ and $57.14 \%$, the 2 subtype $1-2$ had circulated in the two areas of El Hamma and Mahmel with a higher prevalence in the region of Mahmel with $42.85 \%$ in the locality of El Hamma was $27.77 \%$. All viruses isolated by Plateau and Coll.; In France since 2001, as well as viruses isolated by Sidibé and Coll. In 2002 in Mali; Goto, 2002 in Japan and Guo et al., 2003 in China, belonged to the sub type 2. In Tunisia in 2001, Chabchoub et al.; found that horses also presented a significant prevalence for subtype 2; Bousseta et al., 2000 in Tunisia and rejoin the findings of Lucam et al., In 1999 who observed in airway causes more damage A / equi / 2 that found that the virus $A /$ equil$/ 1$. We found that the virus resulted in more $\mathrm{A} /$ /equi/2 sequelae of bronchopneumonia A/equi/1 the virus. Against that Thorsen et al., In 1983 had found in samples of respiratory mucus of horses with bronchopneumonia, a hemagglutination inhibitory activity mainly high to A/equi/1; Ellouze in Tunisia in 2000 stated that the disease recorded between 1998 - 1999 was caused by the subtype 1 , with a prevalence of $10 \%$ for subtype 2.This study showed the existence of cases of mixed infection (infection of the same subject by subtypes 1 and 2) in all areas of the investigation. Sidibé et al. In 2002 in Mali claimed the existence of mixed infections in the type 1 and 2 in all locations surveyed except one and rejoin the findings in 1997 in Saudi Arab united in Matsmura et al., in 2003 in Japan and Moraillon et al., in 1978 in Morocco.

The high rate of infection of donkeys by the influenza virus (ie $31.66 \%$ ) showed that they were more susceptible to disease than horses (or 18.05\%). Thus, the prevalence of infection was higher in El Hamma where the number of donkeys was higher $(25 \%)$. The lowest rate was obtained in the locality where the species Mahmel Equine predominated (ie $23.33 \%$ ). The same observations were reported by Sibidé et al. in 2002 in Mali. Another survey was conducted by Bousseta et al., 2000 in horses in the North-east of Tunisia, by Chabchoub and Coll., Tunisia in 2002, Sibidé and Colll., Mali in 2002 and Moraillon and Coll. 1978 in Morocco these authors confirmed the existence of heterogeneity of the age of seropositive animals against influenza. Nyaga et al., 2000 in Japan fell seroprevalence rates significantly lower in subjects aged less than two months, this was important in the early head where the maximum resistance to disease in the first weeks of life depends on making and absorption of colostral immunoglobulins. The antibodies and other macromolecular proteins were absorbed mainly during the first 24 hours, and so in a way negligible.

\section{CONCLUSION}

The equine influenza virus (subtype 1 and 2) circulated among the equine and donkey populations in the two regions covered by the survey. The study had established a clear predominance of old infections of equine influenza and mules studied (ie $93.75 \%$ ). This study revealed that the subtype 2 occupied a significant role in the genesis of obstructive lesions and chroniques.Ces results deserve to be confirmed by other work including the use of bronchoalveolar lavage (BAL) for the detection of microorganisms in the liquid removed by washing or the technique of neutralization for former condition or techniques related to Advances in molecular biology: molecular probes were particularly valuable in human biology and veterinary medicine. The gene amplification technique, will significantly improve the diagnosis, from clinical samples. Control of influenza in Algeria is essential for Veterinary Services to implement a control program based on health and medical prophylaxis by use of a vaccine based on type 1 and type 2 virus of the disease and a control at the borders. 


\section{REFERENCES}

Chabchoub A ., Louzir H ., et Aouina Th (2001) .Recherche des anticorps précipitants envers Micropolyspora faeni anti thermoactinomyces vulgaris et extraits totaux de foin moisi dans le de chevaux atteints d'affections broncho-pulmonaires chroniques dans le Nord-est de la Tunisie. Revue Méd Vét., 144, 49-55.

Lucam F., Fedida M., Dannacher G., Couder M et Peillon M (1999). La grippe équine. Caractères de la maladie expérimentale. Revue Méd Vét., 125, 1273-1293.

Chabchoub A ., Guelfi JF., et Lescure F (2002). Affections broncho-pulmonaires chroniques du cheval. Contribution à l'étude de la gazométrie sanguine de repos. Pratique Vét Equine., 25 ,5-11.

Fontaine M. (1989). Grippe du cheval. Pratique Vét Equine, 3,9-14.

Jommaa I. (1993).Contribution à l'étude de la grippe équine en Tunisie. Thèse Doct. Méd. Vét. Sidi Thabet.

Authie E (1989).Contribution à l'étude des affections broncho-pulmonaires chroniques du cheval. Thèse Doc Vét .Créteil.

Ministère de l'Agriculture, statistiques, 2006

Sigiura T., Sugita S., Imagawa H., Kanaya T., Ishiyama S., Saeki N., Uchiyama H., Tanigawa M., et Kuwamo A. (2001). Serological diagnosis of equine infuenza using the hemagglutin protein produced in a baculovirus expression system.Vet.Clin.North Am.Equine Pract: 9, 65-82.

Timoney P.J.(2002).Equine viral influenza. O.I.E. Manual of Standards for diagnostic Tests and Vacccines.Paris:2001, 582-594.

Anestad G and Maagaard O (2000). Rapid diagnosis of équine influenza. Vet Rec., 126:550-551.

Sidibé S., Bocum Z., Simbé C.F., Tounkara K., Bakkali M.M et Kané M. (2002).Grippe équine au Mali : résultats d'une enquête séroépidémiologique.Revue Elev. Med Vet. Pays Trop.55 (2).89-92

Bousseta M., Chabchoub A., Ghram A., Jomaa I., Ghorbel A., Aouina $T$ et Ben Amor.(2000) .Enquête séroépidémiologique sur la grippe et l'anémie infectieuse des équidés dans le Nord-est tunisien. Revue Elev. Med Vet. Pays Trop.47.277-281.

Fontaine M., et Moraillon A. (1989).Considération sur l'épizootie de grippe 1987-1988 en France. Rec Méd Vét.156, 139-145
Le Minor $\mathrm{L}$ et Veron M.(1982). Bactériologiemédicale.Paris.France .Flammarion Médecine-Sciences.114-115.

Zientara S., Plateau E.(2002). Vaccins et vaccinations chez le cheval. Point vét.24 : 601-610.

Plateau E., Crucière C., Jacquet A et Cheyroux M.(2001). Mise au point et recherche en cours sur l'évolution épidémiologique et antigénique de la grippe équine en France.Bull.Mens.Soc.Vét.Prat.Fr.60 : 6-10.

Goto H., Shimizu K., Abé T et Kanamitsu M. (2002). Seroepidemiological study on equine influenza in Japon . J Clin Microbiol.2 (2),89-93.

Guo Y., Wang M et Zhang GS. (2003). Seroepidemiological and molecular evidence for the presence of two H3N8 equine influenza viruses in China in 20012002.J.Gen.Virol.76 :2009-2014.

Chabchoub A .,Louzir H ., Aouina Th ., Ghram A., Bousseta M et Jomaa I .( 2001). Recherche des anticorps anti-grippaux dans le sérum de chevaux atteints d'affections broncho-pulmonaires chroniques .Revue Méd.Vét.145 (5) :343-348.

Thorsen J., Willoughby R A.,Mc Donell W., Walli V.E.O.,Viel et Bignell W.(1983). Infuenza hemmmaglutination inhibiting activity in respiratory mucus from Horses with chronic obstructive pulmonary discorders.Can.J.Comp.Med.47 :332-335.

Ellouze M.R.(2002). Contribution à l'étude épidémiologique de l'anémie infectieuse, de l'artérite à virus, de la rhinopneumonie et de la grippe équine en Tunisie. Thèse Doc. Vét. Sidi Thabet.

Arab A.(1997). Equine serological survey 19951996.United Arab Emirats Ministry of Agriculture and Fisheries.

Matsumura T., Komano M. , Sugiura T.,Kamada M. et Fukanaga Y.(2003). Sero-epizootiological studies on viral diseases in horses on a breeding farm in Japan during a period from 2001-2002.Bull of Equine Research Institute. 23 :28-34.

Moraillon A., Moraillon R., Toma B., Sedrati A. et Lahlou Kassi S.(1978). Enquête épidémiologique de l'anémie infectieuse, de l'artérite à virus, de la rhinopneumonie et de la grippe équine au Maroc. Rec. Méd.Vét. $154: 921-928$.

Nyaga PN., Wiggins A.D et Priester W.A.(2000). Epidemiology of equine influenza risk by age, breed and sex. Comp Immun. Microbiol Infects.Dis. 3 : 67-73. 